\title{
MARRIAGE PLOT AS A CHALLENGE TO GENDER CONVENTIONS IN AURORA LEIGH BY ELIZABETH BARRETT BROWNING ${ }^{1}$
}

\author{
Soner KAYA ${ }^{2}$
}

Geliş: 29.07.2021 / Kabul: 24.09.2021

DOI: 10.29029/busbed.976101

\begin{abstract}
Elizabeth Barrett Browning in her long narrative poem titled Aurora Leigh portrays a heroine that struggles to be a poetess rather than a submissive wife in accordance with gender conventions. Her struggle shows that women attempting to go beyond domesticity to pursue a career encounter certain obstacles because marriage is regarded supreme career for them. Despite those obstacles and gender-specific applications, Aurora Leigh, the heroine, becomes a poet and marries her cousin. Her poetic career and marriage display that womanhood is not an obstacle to pursuing a career. By such a plot, Elizabeth Barrett Browning, challenged patriarchal society and the attribution of both frailty and certain fixed roles to women. Rather than presenting a conventional marriage in the end, Browning utilizes an unconventional marriage as a challenge to the patriarchal Victorian society because she underlined the fact that a marriage is not a career for women but a necessity. Discussing unconventionality of the marriage in Aurora Leigh, this study investigates how Browning problematizes conventional gender roles and presents marriage as a part of women's powerful side rather than as a sign of subjection.
\end{abstract}

Keywords: Gender roles, Aurora Leigh, Victorian society, Elizabeth Barrett Browning

\footnotetext{
${ }^{1}$ This article is prepared based on the dissertation titled "Writing as a challenge to Victorian patriarchal values: Elizabeth Browning's Aurora Leigh".

2 Doctorate Student, İstanbul Aydın University, Institute of Social Science, sonerkaya@stu.aydin.edu.tr, ORCID: https://orcid.org/0000-0002-4945-5650.
} 


\section{ELIZABETH BARRETT BROWNING'IN AURORA LEIGGH ADLI ESERINDE GELENEKSEL CINSIYYET ROLLERINE BIR MEYDAN OKUMA OLARAK EVLILIK TEMASI}

\section{$\ddot{O} z$}

Elizabeth Barrett Browning Aurora Leigh başlıklı uzun anlatı şiirinde dönemin geleneksel cinsiyet rolleri doğrultusunda itaatkâr bir eş olmak yerine şair olmak için mücadele eden bir kadını canlandırmaktadır. Kadın kahramanın mücadelesinden anlaşıldı̆̆ı üzere, kadınlar için evlilik tek kariyer olanağı olarak görüldüğ̈̈nden kariyer yapmaya çalışan kadınlar çeşitli engellerle karşılaşmaktadır. Bu engellere ve cinsiyete özgü uygulamalara rağmen, kadın kahraman Aurora Leigh bir şair olmayı başarıp kuzeniyle evlenmektedir. Kahramanın edebi kariyeri ve evliliği kadınlığın kariyer yapmak için bir engel olmadlğını göstermektedir. Böylece, Elizabeth Barrett Browning ataerkil topluma ve kadınlara hem kirllganlık kavramının hem de bazı kısitlayıcı rollerin atfedilmesine meydan okumaktadır. Browning evliliğin kadınlar için bir kariyer olmadı̆̆ın aksine doğaları gereği bir gereklilik olduğunun altını çizmek için eserini geleneksel bir evlilik yerine ataerkil Viktorya toplumunun geleneksel cinsiyet rollerine meydan okuyan bir evlilik ile sonlandirmaktadir. Aurora Leigh'teki evliliğin sıra dışıllğııı tartışan bu çalışma, Browning'in geleneksel cinsiyet rollerini nasıl sorunsallaştırdiğını ve evliliği bir boyun eğme göstergesi olarak değil, kadının güçlü yanının bir parçası olarak değerlendirdiğini göstermektedir.

Anahtar Kelimeler: cinsiyet rolleri, Aurora Leigh, Viktoryen toplumu, Elizabeth Barrett Browning

\section{Introduction}

Victorian period was characterized by economic developments and scientific inventions such as the steamship and the railway system. In this period industrial revolution accelerated the growth and England became a powerful country because of the developed trade and industry. The country was ruled by a queen, Queen Victoria from 1837 to 1901, and despite such advancements in science, industry and trade, there was inequality between the social classes and genders. From working life and education to literature, there were gender specific applications most of which were against women. Unfortunately, some of these injustices were supported by the law and the others were based on the expectations of the society since it labelled womanhood with certain characteristics such as weakness and inferiority. Hence, it would be true to say that in the Victorian 
period, "whatever their social rank ... women were second-class citizens" (Gallagher, 1988, p. 57).

Being in the disadvantaged position in many areas such as education, literature and business, women were considered to be suitable only for domestic work such as sewing, cleaning, growing up children, satisfying males at home. Whether they were married or single, they had to serve male members of their families at home. As Jenni Calder asserts, "the home and the female were inevitably intimately associated" (Calder, 1977, p. 9). Marriage did not change their role of being at home and they kept carrying out the household duties and obeying their husbands. It was so because men were seen as ones who had the heavy burden of the society on them and women were expected to please men since they were superior to women. In other words, a house was regarded "a place of renewal for men, after their rigorous activities in the harsh, competitive public sphere" (Gorham, 1982, p. 4). Therefore, marriage was regarded as the best career for women for societal order, and the patriarchal society believes that "the natural vocation of a woman is that of a wife and a mother" (Mill, 1999, p. 94). All these attitudes towards women were based on the belief that women were born biologically inferior to men and their brains and power were suitable for the domestic sphere. Such difference between the sexes is also suggested by Charles Darwin who said that "the average of mental power in man must be above that of women" (Darwin, 1896, p. 564). He also claimed that men had "a higher eminence, in whatever he takes up, than can women - whether requiring deep thought, reason, or imagination, or merely the use of the senses and hands" (Darwin, 1896, p. 564).

Born into the Victorian society, Elizabeth Barrett Browning tried to overcome the inequalities Victorian women faced in terms of education, as well as legal and social rights. Although she had a similar fate with her contemporaries in terms of deprivation of formal training, she was determined to write with her mostly self-taught nature. Born into the Victorian society, Elizabeth Barrett Browning tried to overcome the inequalities Victorian women faced in terms of education, as well as legal and social rights. She was aware of the fact that writing was like a weapon for women in their struggle for their rights and in their endeavours to make their voice heard by the society. Accordingly, she valued writing and used it as a means of confronting the problems of her age and protesting gender-specific values. Because of such characteristics of her writing, Browning, "was the most celebrated woman poet of the Victorian era. She was admired by contemporaries as varied as William Wordsworth, Queen Victoria, 
Edgar Allan Poe (who introduced an American edition of her work), Christina Rosetti, and John Ruskin (who proclaimed 'Aurora Leigh' the greatest poem in English)" (Henderson \& Sharpe, 2004, p. 528). Thus, through her leading position in poetry as a woman, she problematized the fixed gender roles of her time and the idea that marriage is the supreme career for women.

\section{Discussion}

The heroine of this poem, Aurora Leigh, is a determined, brave and ambitious woman, who strives to struggle against the injustices of her era and to become the mouthpiece of her contemporaries. After the death of her mother during her infancy, she is raised by her father until she becomes thirteen. When her father dies she moves to England where most of the story takes place. Although she encounters some hardships in England, she decides to be a prolific poetess rather than being a hardworking woman in the domestic sphere. Therefore, as Virginia Woolf asserts, Aurora Leigh, "with her passionate interest in social questions, her conflict as artist and woman, her longing for knowledge and freedom, is the true daughter of her age" (Woolf, 1932, p. 229). Here, Woolf's assertion is based on the fact that Aurora struggled with the difficulties of the age, refused to be a stereotypical wife and succeeded in her poetic career. At the end of the poem, Aurora marries her cousin Romney Leigh, whose proposal she refuses earlier because of her determination to be a writer. This marriage may sound paradoxical as Aurora fights against male hegemony but when the whole story is taken into consideration, the contradiction is resolved; at first, she refuses her cousin in order to have a career in writing but then accepts after Romney and his vision of womanhood change. This marriage is based on mutual love and is the "picture of how the two sexes might work together so that each could achieve its fullest human potential" (Henderson \& Sharpe, 2004, p. 529). All in all, Aurora Leigh, as a successful poetess, "attained such a height of poetic excellence, not in spite of her woman's nature, but by means of it" (Everett, 1857, p. 419), and by this way shows that gender cannot be a hindrance in becoming a writer and marriage is not a career for women.

After the heroine arrives in England, her rearing continues in the custody of her aunt, Mrs. Leigh. Her aunt is an unmarried woman who behaves according to the values of the patriarchal society and acts as an agent of the Victorian society, which becomes clear in her rearing. Namely, Aurora's training is in line with preparing her for her future role as a wife and mother. Within the scope of such training, Aurora is taught that women need to "keep quiet by the fire / And never say 'no' when the world says 'ay,' (I.436-437). This also implies that women were the ones who were expected to obey and do their so-called womanly duties in order to be appreciated by the patriarchal society. 
In her training, Aunt Leigh forces Aurora to read some books which are on womanhood and conventional roles in the society. Aurora mentions those books when she says:

I read a score of books on womanhood

To prove, if women do not think at all,

They may teach thinking, (to a maiden aunt

Or else the author) - books demonstrating

Their right of comprehending husband's talk

When not too deep, and even of answering

With pretty 'may it please you,' or 'so it is,'-

(Aurora Leigh I.427-433

Aurora gives some details about the content of those books as she says that they are about teaching women how to behave in their relationship with their husbands. By making Aurora read those books, her aunt aims to fit Aurora into an ideal wife of the future. To be sure that Aurora does her task and reads her books, her aunt supervises her, asking "Aurora, have you done / Your task this morning? - have you read that book?" (I.1036-37). Thus, she checks whether Aurora obeys her training and does her tasks to be prepared for her future position as a wife. Even though Aurora finds it difficult to do whatever her aunt tells her, she obeys her aunt's commands because she does not want to arouse her indignation. However, she conveys her displeasure with her obedience when she says:

At first,

I felt no life which was not patience, - did

The thing she bade me, without heed to a thing

Beyond it, sate in just the chair she placed,

With back against the window, to exclude

The sight of the great lime-tree on the lawn,

In this quote, Aurora implies much more with the position of the chair, she is not allowed to look outside the window which symbolizes women's imprisonment at home in the Victorian period. In Aurora's lines, there is a criticism of such an isolation at her aunt's home as she says "I, alas, / A wild bird scarcely fledged, was brought to her cage" (I. 306-307). She challenges her deprivation of freedom in her aunt's home since she sets an analogy not only between herself and a trapped bird, but also between a cage and her aunt's home. Thus, once more she makes a reference to the imprisonment of girls and women with their conventional roles in the Victorian period. 
As mentioned above, obeying her aunt's commands, Aurora avoids her aunt's indignation and closer supervision and starts to read her father's books in her spare time to develop a poetic mind. Actually, isolating herself in her room to read gives her ample freedom from her restrictive training as a girl, and eventually she becomes determined to have an unconventional life in the future as a woman. She stresses her striving for freeing herself when she says:

... I sat on in my chamber green,

And lived my life, and thought my thoughts, and prayed

My prayers without the vicar; read my books,

Without considering whether they were fit

To do me good.

Here, it is clear that reading her father's books in her free time is her own choice and it provides her a "comparable relief from the constraints of domesticity" (Wallace, 1997, p. 234). In the lines above, she also implies that she frees herself in her chamber by reading what she wants, thinking with her free will and praying as she wants. In this sense, as Gilbert and Gubar assert, "Aurora refuses to submit to her aunt's strictures; early, studying her dead father's books, she decides to become a poet" (Gilbert and Gubar, 1984, p. 575). These books are written by men especially authors of classical literature as Homer and Horace and they help her to learn the poetic tradition. Since she is not allowed to go to school to become a poet, she becomes a self-taught poet and starts to write. Thus, with her determination, she disobeys the norms of the patriarchal society that women do not need proper education as mentioned in the previous chapter.

As an adult in her twenties and being very critical about women's conventional roles in the society, Aurora disagrees with her cousin Romney Leigh on his views about women, their position and roles in the society. While questioning Romney's ideas, she indirectly criticizes Victorian men's vision of womanhood. In one of their conversations, Romney scorns women when he says:

... Women as you are,

Mere women, personal and passionate,

You give us donating mothers, and chaste wives.

Sublime Madonnas, and enduring saints!

(II.220-223)

Here, Romney reflects a stereotypical approach to femininity: he thinks that women are to be mothers or wives and chastity is important for them. In the 
last line of this quote, he attributes an angelic value to women by comparing them to Madonnas and saints. Thus, his thoughts are in parallel with the belief of the Victorian patriarchal society that "the sphere of love, the emotions and domesticity was defined as the sphere of women" (Gorham, 1982,p. 4). Although he is a man who strives to reform the class system and set an equality between classes, his approach to genders is not different from the society he lives in. By this way, he acts as an agent of the Victorian patriarchal society because his approach to femininity is part of men's vision of womanhood.

Upon his declaration of women and their roles, Romney proposes Aurora to marry him and help him in his philanthropic activities. In her reply to him, Aurora criticizes Romney, saying:

... What you love,

Is not a woman, Romney, but a cause:

You want a helpmate, not a mistress, sir,-

A wife to help your ends. In her no end!

Your cause is noble, your ends excellent,

But I, being most unworthy of these and that,

Do otherwise conceive of love.

$$
\text { (II.400-406) }
$$

Having understood Romney's views about women, Aurora rejects his marriage proposal, because she believes that Romney's marriage proposal is not based on love and he wants her to be his wife who will help him in his activities. Asking Aurora to marry him in a conventional sense and be a chaste wife according to the values of patriarchal society, he ignores Aurora's goals. Thus, marrying him will make Aurora a conventional Victorian woman serving her husband in the domestic sphere. However, her refusal of marriage proposal by Romney shows that she does not accept gender divisions. This is a challenge to traditional marriages of the age. Aurora says:

You misconceive the question like a man,

Who sees a woman as the complement

Of his sex merely. You forget too much

That every creature, female as the male,

Stands single in responsible act and thought 
As also in birth and death.

$$
\text { (II.434-439) }
$$

Actually, Aurora's refusal of marriage is an expression of strong opposition to men's approach to marriage and women. She tells Romney that he thinks in the same way with the Victorian patriarchal society and he forgets that women are not mere helpers and they have their thoughts, goals and responsibilities. Thus, her words show that she denies the conventional roles of a wife for the sake of being a powerful woman. As Gilbert and Gubar suggest, Aurora's cousin "asks her to become his wife and helpmate, she proudly declines his offer, explaining that she has her vocation, too: art, which is at least as necessary as social service" (Gilbert and Gubar, 1984, p. 576). The critics affirm how important Aurora's refusal in terms of her sex and her vocation is. Mentioning her refusal of the marriage proposal, Aurora claims," If I married him, / I would not dare to call my soul my own" (II. 785-786). Thus, she tells that by refusing to marry her cousin, she takes an important step towards freeing her soul as an independent woman poet, and "she firmly rejects all forms of patriarchal constraint" (Martinez, 2012, p. 18). All in all, her reply to Romney is a criticism of Victorian marriage institution and men's conventional approach to the concept of a subservient wife.

Aurora's debate on women during her adulthood also shows that those women who plan to engage with something beyond the domestic sphere may have some trouble. This is also understood for Romney's words when he says: “... keep to the green wreath / Since even dreaming of the stone and bronze / Brings headaches, pretty cousin..." (II.93-95). In the quote, the difficulty of having a career for a woman in the Victorian period is suggested through the headache metaphor. However, as a powerful woman who challenges the Victorian patriarchy even during her early years as mentioned in the previous chapter, Aurora Leigh is determined not to give up, saying:

... I would rather take my part

With God's Dead, who afford to walk in white

Yet spread His glory, than keep quiet here,

And gather up my feet from even a step,

For fear to soil my gown in so much dust.

I choose to walk at all risks.-Here, if heads

That hold a rhythmic thought, must ache perforce,

For my part, I choose headaches

(II.101-108). 
Here, Aurora's words show her courage and determination because she clearly states that she is ready to bear any obstacle on her way towards having a career rather than keeping quiet as a wife. She is not afraid of taking risks and getting into trouble which those women acting against the so-called ideal Victorian woman may encounter. Thus, Aurora's words reflecting her determination above "convey a metaphorical meaning that alludes to Aurora's unusual decision to become a professional writer" (Carion, 2003, p. 784), and this determination shows her insistence "on women's primary moral and political responsibility to engage in serious work" (Lewis, 2007, p. 129).

Aurora's poetic career for which she declares her purpose at the beginning of her work is still immature during the first years of her adulthood. She describes herself as a woman artist in the first years of her twenties when he says: "... I stood / Woman and artist,-either incomplete, / Both credulous of completion" (3-5). In her words, it is clear that she does not separate her femininity and art which are seen as two clashing terms in the Victorian period as discussed in the previous chapter. Although she describes both her womanhood and art as incomplete, Aurora gives the sign of her future success as a woman and poetess despite the gender inequalities in the field of poetry. Throughout her work in which she is the protagonist, she mirrors aforementioned gender inequalities of her age because she not only tells the difficulties she bears until she becomes a poetess, but she also challenges her age and searches for social reform through writing as a woman. She values writing about her own age and claims that poets' "sole work is to represent the age/ Their age" (V. 202-203).

Through his conversation with Aurora on women and writing, Romney reflects men's approach to women's participation in poetry, saying:

Here's a book I found!

No name writ on it—poems, by the form;

Some Greek upon the margin,-_lady's Greek

Without the accents. Read it? Not a word.

I saw at once the thing had witchcraft in 't,

Whereof the reading calls up dangerous spirits:

I rather bring it to the witch.

Here, it is clear that Romney underestimates women's poetry because when he finds a book whose writer is unknown, he thinks that it must have been 
written by a woman poet, so before reading it he decides that it is full of witchcraft. Just like his views about women's roles as wives, Romney reflects the patriarchal way of thinking about women and verse writing in the Victorian period. While he is talking about the book he finds, he tells how he understands that it belongs to a woman since it seems worthless. Accordingly, Alison Case asserts, "Romney here represents the whole weight of male social authority, discouraging women from writing by assuring them that anything they do will inevitably be second-rate" (Case, 1991, p. 24). All in all, Romney thinks that like other women, Aurora "does not have sufficient knowledge or sympathy to be a successful poet" (Rotunno, 2008, p. 59). Therefore, in addition to ridiculing Aurora's art, he also tries to discourage Aurora from writing when he says:

...If your sex is weak for art,

(And I who said so, did but honour you

By using truth in courtship) it is strong

For life and duty...

\section{(II.373-376)}

Emphasizing his sincerity in a love relationship that women's nature is suitable for serving at home rather than writing poems, he displays men's conventional mind-set about women's writing and duties in the society.

As a consequence of this patriarchal mentality in the Victorian period, Aurora and other women encounter strict obstacles and inequalities in the formation of their poetic career because of their sex. Actually, as they cannot participate in poetry on equal terms with men, there are not many women poets, and their absence makes Aurora Leigh more significant as it is one of the important texts by a woman poet in the Victorian period. Aurora values women's participation in the poetry and opposes those women complying with the norms of the society as she says: "How dreary 'tis for women to sit still / On winter nights by solitary fires, / And hear the nations praising them far off" (V. 439-441). She disapproves women's behaviour according to the values of the Victorian patriarchal society. She believes that women need to pursue their goals no matter what is expected of them by patriarchy.

After her aunt's death, Aurora moves to London to pursue her aim of writing with a sum of money she inherits from her aunt. Despite the gender inequalities and difficulties, Aurora succeeds in establishing a poetic career upon her move to London, mainly because she has a "room of her own" (Woolf, 2012, p. 29), as Woolf suggests, to concentrate on her art. She says: "The room does very well; I have to write / Beyond the stroke of midnight" (III. 26-27). Accordingly, as Cora Kaplan claims, "the description of Aurora as an independent 
author living and working in London was possibly the most revolutionary assertion in the poem" (Kaplan, 1978, p.36).

Like her poetic career, Aurora's marriage is also significant as it is different from common marriages in the Victorian period. Although Aurora seems to comply with the norms of the society by marrying Romney, her marriage is not based on the acceptance of the conventional gender roles, because her marriage is not a barrier to her poetic career. Aurora accepts Romney's proposal, which she refused earlier for the sake of becoming a poet, after she changes Romney's vision of femininity and poetry. As Romney utters:

$\ldots$ in this last book,

You showed me something separate from yourself,

Beyond you; and I bore to take it in,

And let it draw me. You have shown me truths

(VIII. 605-608)

Romney's utterance above implies that Aurora has established a successful career and changed even a man's conventional point of view about women and writing. Thus, Romney accepts that he has understood the truths about women whom he ridiculed earlier and criticizes his earlier behaviour as he says: "I was not worthy" (VIII. 323). He also claims:

I should push

Aside, with male ferocious impudence,

The world's Aurora who had conned her part

On the other side the leaf! ignore her so,

Because she was a woman and a queen,

And had no beard to bristle through her song,-

My teacher, who has taught me with a book

(VIII. 327-333).

In the lines above, Romney admits that he has ignored Aurora and her art due to her sex, and utters that this is a sign of disrespect to women. He puts away such a thought. Addressing Aurora as his teacher is an indication of the fact that Aurora succeeds in social reform through her art. Therefore, by marrying Romney, Aurora does not conform to the stereotypical roles as a Victorian woman but she shows that it is not a necessity to sacrifice either love or her art for the sake of the other. Also, she shows how important love is when she says: "art is much, but love is more" (IX.656). Womanhood and poetry are proved to be two reconcilable terms, when Aurora underlines that "it is not so much unfeminine to be a poet" (Zonana, 1989, p. 249). For Aurora's marriage, Alison Case asserts, 
"after many misunderstandings both trivial and profound, Aurora and Romney are united, and the meaning of their lives is seen retroactively to lie in the struggle to bring art, love and social improvement into relation with each other - a struggle which achieves symbolic success in their marriage" (Case, 1991, p. 22). In this quote, Case also confirms that this marriage is a result of the combination of art, love and social reform, and could be accepted as a success rather than a conformity to the Victorian ideals.

\section{Conclusion}

Finally, in Aurora Leigh, the heroine narrates her adventures she experienced on her way towards being a poet in a strictly patriarchal society rather than being a submissive wife. In her narration of her childhood, she describes her rearing and her struggles as a young girl in the Victorian period. After her childhood, she also recounts her experiences as an adult woman and her strivings to be a poet which started in her infancy. Also, she conveys that she succeeds in establishing a poetic career despite the obstacles. Lastly, in addition to her poetic career, Aurora's marriage is also significant as it shows that wife and husband can participate in the various spheres on equal terms and it is not unfeminine to be a poet. All in all, through her childhood, adulthood, writing career and marriage, Aurora reflects the period she lives in and challenges the gender inequalities of the patriarchal society.

\section{References}

BROWNING, E. B. (2008), Aurora Leigh, Oxford: Oxford University Press.

CALDER, Jenni (1977), The Victorian Home, London: Batsford.

CARION, M. D. N. (2003), “The Influence of Elizabeth Barrett Browning's Aurora Leigh over Elizabeth Stuart Phelps's The Story of Avis", Fifty Years of English Studies in Spain (1952-2002), A Commemorative Volume. Ed. Couso, M. J. L. et. al. Santiago de Compostela: University of Santiago de Compostela press.

CASE, A. (1991), "Gender and Narration in Aurora Leigh”, Victorian Poetry, 29 (1), 17-32.

DARWIN, C. (1896), The Descent of Man and Selection in Relation to Sex, New York: D. Appleton and Company.

EVERETT, C. C. (1857), North American Review, 85 (177), 415-41.

GALLAGHER, C. (1988), The Industrial Reformation of English Fiction: Social Discourse and Narrative Form, 1832-1867, Chicago: University of Chicago Press. 
GILBERT, S. M., \& Gubar, S. (1984), The madwoman in the attic: The woman writer and the nineteenth-century literary imagination, New Haven: Yale University Press.

GORHAM, D. (1982), The Victorian girl and the feminine ideal, Bloomington: Indiana University Press.

HENDERSON, H. and SHARPE, W. (2004), "Elizabeth Barrett Browning 1806 1861", The Longman Anthology of British Literature. Gen. Ed. Damrosch, D. Volume B. Newyork: Pearson Longman.

KAPLAN, C. (1978), Aurora Leigh and Other Poems, London: Women's Press.

LEWIS, B. W. (2007), That Idyl of the June, That Girls' Gospel: Elizabeth Stuart Phelps and Browning's Aurora Leigh. Womanhood in Anglophone Literary Culture: Nineteenth and Twentieth Century Pespectives, Ed. Hammerman, R. Newcastle, U.K: Cambridge Scholars.

MARTINEZ, C. M. (2012), Elizabeth Barrett Browning's Aurora Leigh: A Reading Guide, Edinburgh: Edinburgh University Press.

MILL, J. S. (1999), The subjection of women. His contemporary and modern critics, Ed. Jacobs, L. A. and Vandewetering, R. Delmar, N.Y: Caravan Books.

ROTUNNO, L. (2008), "Writers of Reform and Reforming in Aurora Leigh and a Writer of Books", Gender and Victorian Reform. Ed. Rose, A. Newcastle, U.K: Cambridge Scholars.

WALLACE, A. D. (1997), "Nor in Fading Silks Compose: Sewing, Walking, and Poetic Labor in Aurora Leigh", ELH, 64 (1), 223-256. Retrieved from http://www.jstor.org/stable/30030252

WOOLF, V. (1932), Aurora Leigh, The Second Common Reader. New York: Harcourt Brace.

WOOLF, V. (2012), A Room of One's Own, Ware, Hertfordshire: Wordsworth Classics.

ZONANA, J. (1989), "The Embodied Muse: Elizabeth Barrett Browning's Aurora Leigh and Feminist Poetics", Tulsa Studies in Women's Literature. 8 (2), 240-262. 